\title{
Cytogenetic study of three closely related species of Hawaiian Drosophila
}

\author{
JAYNE N. AHEARN \\ Department of Genetics, University of Hawaii, Honolulu, HI, U.S.A. 96822 \\ AND \\ VISUT BAIMAI ${ }^{1}$ \\ Department of Biology, Faculty of Science, Mahidol University, Bangkok, Thailand

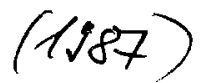 \\ Corresponding Editor: R. S. Singh \\ Received March 12, 1986 \\ Accepted October 22, 1986
}

\begin{abstract}
Ahearn, J. N., and V. Baimai. 1987. Cytogenetic study of three closely related species of Hawaiian Drosophila. Genome, 29: $47-57$.

Three allopatric species from the Hawaiian islands, Drosophila bostrycha (Molokai), D. affinidisjuncta (West Maui), and D. disjuncta (East Maui), are extremely similar in morphology but differ in metaphase chromosomes by the amount and distribution of heterochromatin. Their polytene chromosomes are virtually homosequential with only slight differences at the tip of the microchromosome. Each is polymorphic for one or more inversions, especially in chromsome 4 . Salivary gland chromosomes of $F_{1}$ larvae reared either from wild-caught females or wild-caught males mated to standard laboratory stocks were examined for gene arrangements. Drosophila bostrycha and $D$. affinidisjuncta share a polymorphism for inversion $4 \mathrm{v}$, which is much more frequent in the latter than in the former. In $D$. disjuncta $4 \mathrm{v}$ has been found only joined in a haplotype with three other inversions $\left(\mathrm{g}^{2} \mathrm{~h}^{2} \mathrm{i}^{2}\right)$ at a low frequency at Kipahulu Valley. Drosophila disjuncta is unique in having another fourth chromosome inversion, $4 \mathrm{k}$, which is highest in frequency at Waikamoi. A new inversion, 2s, was discovered at Uluini Stream. Interspecific hybridizations were carried out in small mass matings. Backcrosses and dissections demonstrated that all $\mathrm{F}_{1}$ females were fertile. All $F_{1}$ males were sterile in either of two categories with reciprocal hybrids uniformly manifesting one or the other type. Attempts to model the sterility mechanism suggest that more than chromosomal sterility is involved. Our results are discussed in relation to other closely related clusters of species having heterochromatin-based karyotype variations.
\end{abstract}

Key words: heterochromatin, hybrid sterility, inversion, polymorphism, species divergence.

Ahearn, J. N., et V. Baimai. 1987. Cytogenetic study of three closely related species of Hawaiian Drosophila. Genome, $29: 47-57$.

Trois espèces allopatriques des Iles Hawaï, Drosophila bostrycha (Molokai), D. affinidisjuncta (Maui, ouest) et $D$. disjuncta (Maui, est) sont très semblables dans leur morphologie, mais elles diffèrent au niveau des chromosomes en métaphase par la quantité et la distribution de l'hétérochromatine. Leurs chromosomes polytènes sont virtuellement homoséquentiels, n'offrant que d'infimes différences à l'extrémité des microchromosomes. Chacun d'eux est polymorphe en fonction d'une ou de plusieurs inversions, en particulier le chromosome 4 . Les chromosomes de la glande salivaire des larves de la $\mathrm{F}_{1}$, dont l'élevage provient soit de mâles ou de femelles sauvages capturés et accouplés avec les stocks standard de laboratoire, ont été examinés pour en étudier la disposition des gènes. Drosophila bostrycha et $D$. affinidisjuncta ont en commun un polymorphisme pour l'inversion $4 \mathrm{v}$, laquelle est plus fréquente cependant chez la seconde espèce. Chez $D$. disjuncta, la $4 \mathrm{v}$ n'a été trouvée que chez un haplotype possédent trois autres inversions $\left(\mathrm{g}^{2} \mathrm{~h}^{2} \mathrm{i}^{2}\right)$ de faibles fréquences, provenant de la vallée de Kipahulu. Drosophila disjuncta est unique, en ce qu'elle possède une autre inversion du quatrième chromosome, la $4 \mathrm{k}$, laquelle présente la plus haute fréquence à Waikamoi. Une nouvelle inversion, la $2 \mathrm{~s}$, a été découverte à Uluini Stream. Des hybridations interspécifiques ont été obtenues suite à des accouplements par petits groupes. Des rétrocroisements et des dissections ont démontré que toutes les femelles $F_{1}$ étaient fertiles. Tous les mâles $\mathrm{F}_{1}$ étaient stériles chez l'une ou l'autre des catégories dont les hybrides réciproques manifestaient uniformément l'un ou l'autre type. Des tentatives de modélisation du mécanisme de stérilité suggèrent que la stérilité chromosomique n'est pas seule à être impliquée. Nos résultats sont discutés en fonction d'autres groupes étroitement reliés qui présentent des variations de caryotypes basées sur l'hétérochromatine.

Mots clés: hétérochromatine, stérilité des hybrides, inversion, polymorphisme, divergence des espèces.

[Traduit par la revue]

\section{Introduction}

Evolutionary studies of the species belonging to the family Drosophilidae endemic to the Hawaiian Archipelago have contributed greatly toward the understanding of speciation. Because the Hawaiian Islands are of recent geologic formation, the events of species formation on these islands have been likewise recent. Concentrating on the members of the picturewinged group of Hawaiian Drosophila, Carson and co-workers (reviewed in Carson and Yoon 1982) have documented, from morphological, cytological, and geographical distribution studies, the existence of some 103 species showing various degrees of divergence.

Distinct phylogenetic relationships have been postulated among the picture-winged Drosophila based on the analysis of

\footnotetext{
${ }^{1}$ Author to whom reprint requests should be addressed.
}

polytene chromosomes (Carson and Kaneshiro 1976; Carson and Yoon 1982). Within the D. grimshawi subgroup is an especially interesting cluster of three closely related species, $D$. bostrycha, $D$. disjuncta, and $D$. affinidisjuncta, which are virtually homosequential (Carson and Stalker 1968; Clayton et al. 1972); that is, they share a standard sequence of polytene chromosome bands (Carson and Kaneshiro 1976). These species share a polymorphism for a fourth chromosome inversion (4v) (Carson and Sato 1969). Morphologically, the three are very similar (Hardy 1978). Each is endemic to one of three separate volcanic domes, two on the island of Maui and one on the island of Molokai. Further study of this species cluster may provide additional information on species differentiation and suggest modes of speciation for insular organisms. Presented here are the results of chromosome analyses and hybridization experiments of this species cluster. 
TABLE 1. Locations and dates of Drosophila from Molokai and Maui

\begin{tabular}{|c|c|c|c|}
\hline Species & Location & $\begin{array}{l}\text { Collection } \\
\text { dates }\end{array}$ & $\begin{array}{l}\text { Collection } \\
\text { code }\end{array}$ \\
\hline D. bostrycha & $\begin{array}{l}\text { South Hanalilolilo, } \\
\text { Central Molokai, } 920 \mathrm{~m}\end{array}$ & $\begin{array}{l}\text { July } 9-11,1973 \\
\text { January } 9-11,1975 \\
\text { April } 8-9,1975 \\
\text { July } 15-19,1975\end{array}$ & $\begin{array}{l}\text { S-16 } \\
\text { T-38* } \\
\text { T-46 } \\
\text { T-60 }\end{array}$ \\
\hline D. affinidisjuncta & $\begin{array}{l}\text { Apee, East Molokai, } 520 \mathrm{~m} \\
\text { Kaulalewelewe, West Maui, } 920 \mathrm{~m} \\
\text { Hanaula, West Maui, } 1220 \mathrm{~m}\end{array}$ & $\begin{array}{l}\text { September } 24-26,1973 \\
\text { July } 5-7,1973 \\
\text { September } 26-28,1973 \\
\text { April } 10-12,1975\end{array}$ & $\begin{array}{l}S-30 \\
S-15^{*} \\
\text { S-36 } \\
\text { T-47 }\end{array}$ \\
\hline D. disjuncta & $\begin{array}{l}\text { Waikamoi, East Maui, } 1220 \mathrm{~m} \\
\text { Waikamoi, East Maui, } 1070 \mathrm{~m} \\
\text { Waikamoi, East Maui, } 1070 \mathrm{~m} \\
\text { Waikamoi, East Maui, } 1170 \mathrm{~m} \\
\text { Uluini Stream, East Maui, } 490 \mathrm{~m} \\
\text { Kipahulu Valley, East Maui, } 670 \mathrm{~m}\end{array}$ & $\begin{array}{l}\text { April 9-10, } 1974 \\
\text { April 9-10, 1974 } \\
\text { October } 24-26,1974 \\
\text { April 9-10,1974 } \\
\text { November } 23-24,1973 \\
\text { January } 14-15,1974\end{array}$ & $\begin{array}{l}\text { S-69 } \\
\text { S-72 } \\
\text { T-27 } \\
\text { S-70 } \\
\text { S-48 } \\
\text { S-56 }\end{array}$ \\
\hline
\end{tabular}

* used only in hybridization crosses.

\section{Materials and methods}

Samples of the three species were collected from various populations within the known geographic distributions (Table 1). Drosophila bostrycha is endemic to central and eastern Molokai (Fig. 1). Drosophila disjuncta inhabits the rainforests on the slopes of Haleakala Crater, East Maui, ranging from Waikamoi in the north to Kipahulu Valley in the southeast (Carson and Sato 1969). Drosophila affinidisjuncta is known only from West Maui (Hardy 1978; Baimai and Ahearn 1978). These three species oviposit and feed as larvae upon two endemic host plants, Freycinetia and Clermontia, which are quite common on Molokai and Maui (Montgomery 1975).

Males and females from the field were isolated and the $F_{1}$ subjected to cytological study in the laboratory. $F_{1}$ larvae were reared from each female (isofemale line). Wild-caught males were crossed individually to virgin females from a laboratory stock with known band sequences. Acetoorcein squash perparations of salivary gland chromosomes were made, polytene band sequences were observed under the light microscope, and frequencies of arrangements calculated according to the method of Carson and Sato (1969). Methods for examination of metaphase chromosomes have been described in Baimai (1977). Chromosmes in mitotic anaphase were studied to determine the position of the centromeres. Anaphases were obtained from third instar larval ganglia dissected in $0.7 \%$ saline, swelled in $1 \%$ sodium citrate, fixed in Carnoy's 3:1, stained in 2\% acetoorcein, and squashed in $45 \%$ acetic acid.

Hybridizations were made in nearly all possible combinations between the seven populations of the three species (Fig. 2). Laboratory stocks of $D$. bostrycha, $D$. affinidisjuncta, and $D$. disjuncta were derived from individual wild-caught females. These isofemale lines were cultured at $20^{\circ} \mathrm{C}$ by standard methods developed for Hawaiian Drosophila (Wheeler and Clayton 1965). Adult flies were separated by sex after eclosion and aged to sexual maturity (3 to 5 weeks). Hybridizations were performed in small mass matings of three to five pairs per vial. Parents were brooded weekly. Wheeler-Clayton medium in the mating vials was supplemented with Clermontia juice (water extract of Clermontia leaves) and small pieces of rotted Freycinetia bark to make conditions favorable for oviposition.

$F_{1}$ hybrid adults were collected after eclosure, aged, and subsequently tested for fertility. $F_{1}$ males (aged at least 4 weeks) were dissected and the testes examined microscopically for the status of spermatogenesis. $F_{1}$ males consistently fell into either of two classes of sterility. These classes were distinguished by the stage of spermatogenesis at which sperm development was arrested as well as general morphology of the testes (adopted from Craddock 1975). Sterility class I was characterized by presence of cells and cell debris within testes of reduced size and with reduced number of coils. Sterility class II was typified by presence of all stages of spermatogenesis within a testis of normal morphology but absence of any mature, motile sperm within the vasa deferentia.

$F_{1}$ hybrid females were backcrossed to males of the parental populations. Flies were transferred to fresh food vials weekly and old vials were examined for the presence of larvae. Crosses were allowed to proceed for a maximum of 8 weeks; then the females were dissected and the ovaries and sperm storage organs examined microscopically for presence of mature eggs and sperm, respectively.

\section{Polytene chromosome analysis}

Detailed analysis of polytene chromosome band sequences revealed population as well as species differences. Rearrangements of the standard band sequences (i.e., the polytene band sequences of $D$. grimshawi) were observed primarily in chromosome 4 (Table 2). Each population of the three species sampled carried the standard arrangement at frequencies ranging from $100 \%$ in $D$. bostrycha at Apee to $15 \%$ in $D$. affinidisjuncta from Hanaula.

The inversion of band sequence on the fourth chromosome called 4v (described by Carson and Stalker 1968) is seen in all three species. This inversion is most common in $D$. affinidisjuncta, being present in $78.4 \%$ of fourth chromosomes at Kaulalewelewe and in $85 \%$ of fourth chromosomes at Hanaula. Drosophila bostrycha from South Hanalilolilo had $4 \mathrm{v}$ at a frequency of $51.2 \%$. However, $D$. bostrycha collected from Apee did not carry the $4 \mathrm{v}$ inversion. In $D$. disjuncta, $4 \mathrm{v}$ appeared only in combination with three additional and overlapping inversions, $\mathrm{g}^{2}, \mathrm{~h}^{2}$, and $\mathrm{i}^{2}$ (breakpoints described in Carson 1969). This complex set of inversions occurs only in the Kipahulu Valley population as an unrecombined haplotype having a frequency of $1.9 \%$. However, at $915 \mathrm{~m}$, a higher elevation than our sampling location, this complex was present at an average frequency of 15.8\% (Carson and Sato 1969).

All populations of $D$. disjuncta sampled exhibited inversion $4 \mathrm{k}$ (described in Carson 1969) which is absent from $D$. bostrycha and $D$. affinidisjuncta. The frequency of inversion $4 \mathrm{k}$ varies from $0.5 \%$ in the Kipahulu Valley population to $80.4 \%$ in the higher altitude Waikamoi population. A new rearrangement of chromosome 2, denoted as 2 s (Fig. 3), was found in one of the 36 chromosomes examined from the Uluini Stream population. The breakpoints of this inversion are mapped in 


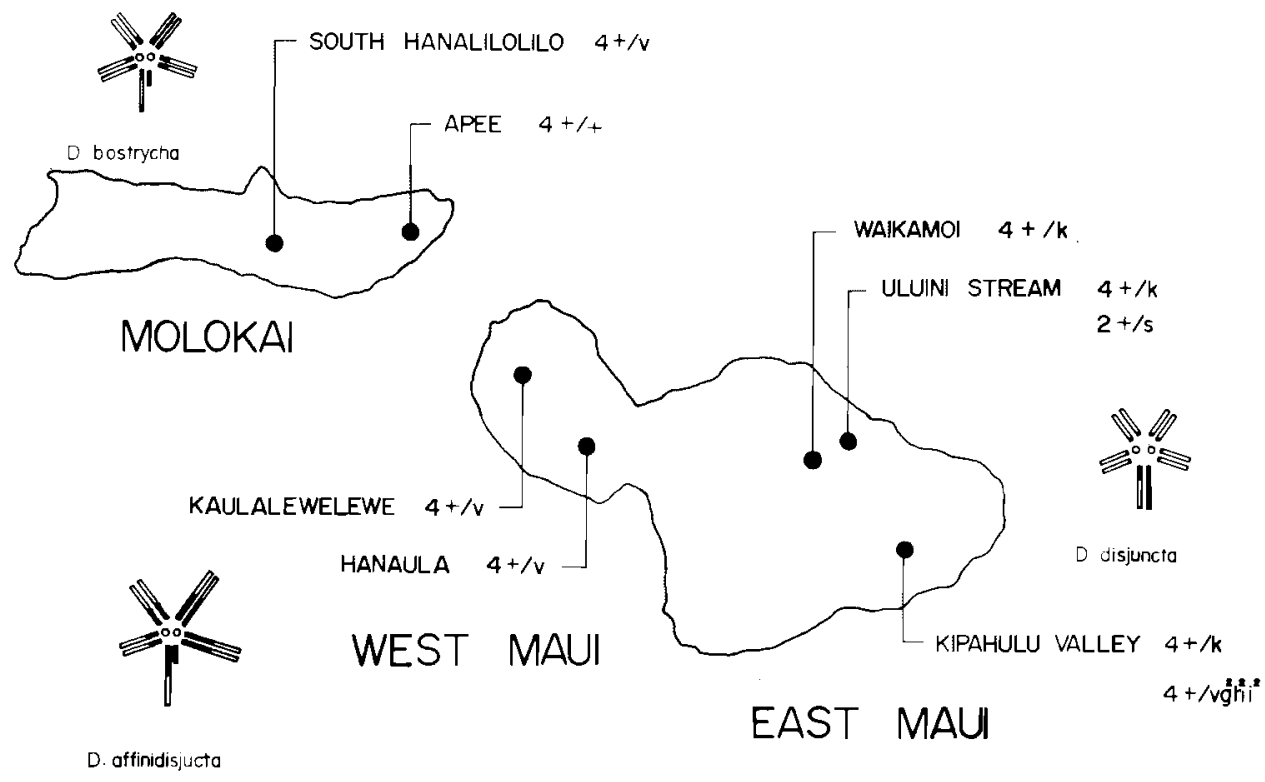

$\stackrel{2}{0 \quad 30 \quad 30} \mathrm{~km}$

Fig. 1. Geographic distributions, metaphase karyotypes, and sali vary gland chromosome gene arrangements of $D$. bostrycha (Molokai), D. affinidisjuncta (West Maui), and D. disjuncta (East Maui).

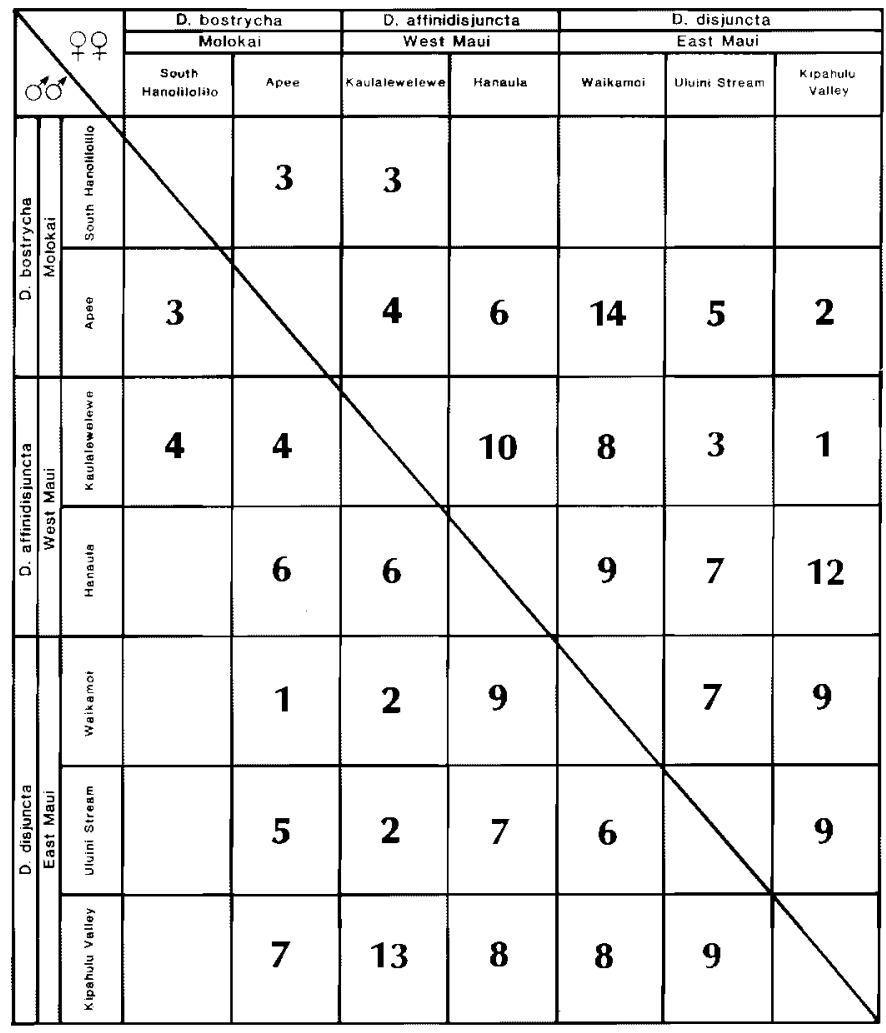

Fig. 2. Matrix of intra- and inter-specific hybridizations. Within each square is the number of small mass matings set up for the cross. Empty squares are crosses which were not made.

Carson 1983. The second chromosome of all other species' populations was monomorphic.

The polytene salivary gland chromosomes of $F_{1}$ interspecific hybrid larvae have also been examined. All major chromosome arms are completely synapsed. The exception is chromosome 6 , the microchromosome or dot in mitotic metaphases. Drosophila disjuncta has a few additional small bands at the distal tip of chromosome 6 , which are absent from $D$. bostrycha and $D$. affinidisjuncta. $\ln \mathrm{F}_{1}$ hybrids of the latter two species, the band sequence of chromosome 6 is identical and the homologues synapse (Fig. $4 a$ ). In contrast, chromosome 6 in $F_{1}$ hybrids of $D$. disjuncta and $D$. bostrycha or $D$. affinidisjuncta shows some asynapsis (Figs. $4 b$ and $4 c$ ). The additional bands of the $D$. disjuncta homologue are very evident in these hybrids.

The chromosomes of the three species as they appear at mitotic anaphase are presented in Fig. 5. These are all female complements so no conclusion can be made about the $\mathrm{Y}$ chromosome. However, it is clear that all the major autosomes and the $\mathrm{X}$ chromosome are acrocentric.

\section{Intraspecific hybridizations}

Crosses between populations within each species were easily obtained. In every case $F_{1}$ females were fertile as assessed by backcrosses to parental population males and dissections of reproductive systems (Table 3 ). $F_{1}$ adult sex ratios were measured at eclosion (Table 4). Males and females appeared in roughly equal numbers in $D$. bostrycha. The sex ratio in interpopulation $\mathrm{F}_{1}$ hybrids of $D$. affinidisjuncta was in favor of females. Among the four $D$. disjuncta interpopulation crosses examined there was significant variation in sex ratio as indicated by the heterogeneity $\chi^{2}$ test $\left(\chi^{2}=20.471, p=0.01\right)$. However, if the most aberrant cross (Waikamoi $\times$ Uluini Stream) is removed from the data, the heterogeneity becomes nonsignificant $\left(\chi^{2}=2.502, p=0.2-0.3\right)$ and the $\chi^{2}$ of the pooled data borders on significance $\left(\chi^{2}=3.608, p=0.05-0.1\right)$. Thus, the interpopulation $F_{1}$ hybrids tend to have a deviant sex ratio in favor of females in $D$. disjuncta.

Reproductive systems of mature (approximately 4 week old) $F_{1}$ males were examined for each intraspecific cross (Fig. 6). All crosses yielded fertile males. However, a small but significant number of $D$. affinidisjuncta males from the Hanaula $\times$ Kaulalewelewe cross were sterile, lacking any mature, motile sperm. Within the $D$. disjuncta interpopulation crosses, two 
TABLE 2. Frequencies (\%) of fourth chromosome gene sequences in populations of $D$. bostrycha, $D$. affinidisjuncta, and $D$. disjuncta

\begin{tabular}{|c|c|c|c|c|c|c|c|}
\hline \multirow[b]{2}{*}{ Species and locality } & \multicolumn{2}{|c|}{$\begin{array}{l}\text { No. of } \\
\text { individuals } \\
\text { tested }\end{array}$} & \multirow{2}{*}{$\begin{array}{c}\text { No. of } \\
\text { chromosomes } \\
\text { examined }\end{array}$} & \multicolumn{4}{|c|}{ Arrangement } \\
\hline & $q q$ & $\partial \delta$ & & $4+$ & $4 \mathrm{k}$ & $4 v$ & $4 \mathrm{vg}^{2} \mathrm{~h}^{2} \mathrm{i}^{2}$ \\
\hline \multicolumn{8}{|l|}{ D. bostrycha } \\
\hline $\begin{array}{l}\text { South Hanalilolilo } \\
\text { (S16, T46, T60) }\end{array}$ & 14 & 12 & 80 & 48.8 & - & 51.2 & - \\
\hline Apee (S30) & 13 & - & 52 & 100.0 & - & - & - \\
\hline \multicolumn{8}{|l|}{ D. affinidisjuncta } \\
\hline Kaulalewelewe (S36) & 29 & 9 & 134 & 21.6 & - & 78.4 & - \\
\hline Hanaula (T47) & 3 & 4 & 20 & 15.0 & - & 85.0 & - \\
\hline \multicolumn{8}{|l|}{ D. disjuncta } \\
\hline Waikamoi (S69, S70) & 12 & 2 & 51 & 19.6 & 80.4 & - & - \\
\hline Waikamoi (S72) & 7 & 6 & 37 & 27.0 & 73.0 & - & - \\
\hline Uluini Stream (S48) & 6 & 6 & 36 & 97.2 & 2.8 & - & - \\
\hline Kipahulu Valley (S56) & 38 & 30 & 212 & 97.6 & 0.5 & - & 1.9 \\
\hline
\end{tabular}

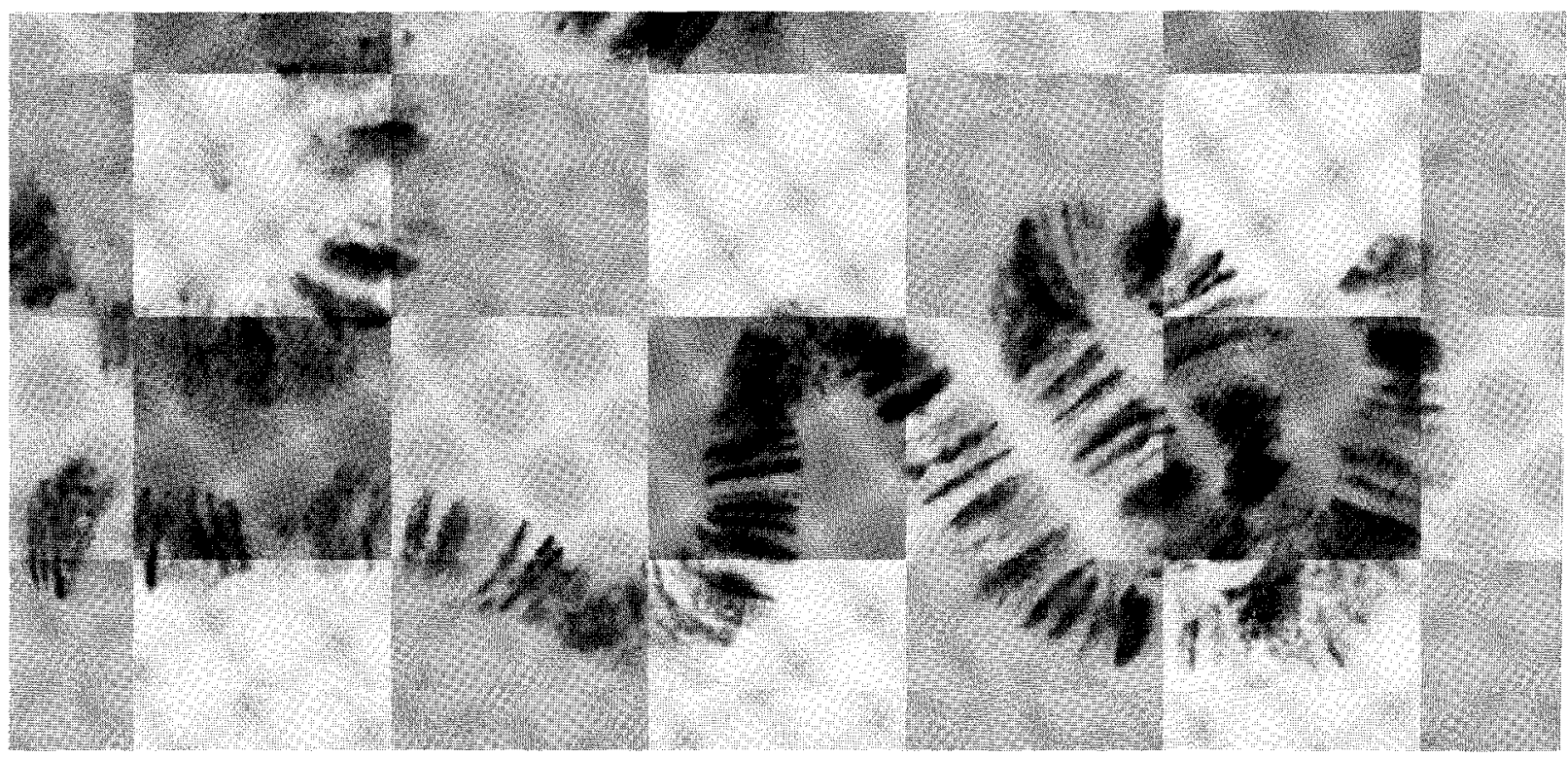

FIG. 3. Heterozygous inversion $2 \mathrm{~s} /+$ from the Uluini Stream population of $D$. disjuncta.

resulted in a percentage of males that were class II sterile. In both cases the cross involved males of the Uluini Stream population and females of another population. When the stock used for these crosses was tested against another isofemale line from Uluini Stream, all $\mathrm{F}_{1}$ males were fertile $(n=26)$.

\section{Interspecific hybridizations}

Hybridizations of the three species were obtained with varying degrees of difficulty. $F_{1}$ hybrid females, however, were fertile (Table 5). In backcrosses nearly every mating yielded $\mathrm{BC}_{1}$ larvae. Dissections showed that $\mathrm{F}_{1}$ females had completely normal reproductive systems and in most cases had been inseminated.

Male and female $F_{1}$ hybrids of $D$. bostrycha and $D$. affinidisjuncta appear in approximately equal numbers (Table 6 ). Likewise the cross $D$. bostrycha $\times D$. disjuncta and its reciprocal yield progenies with a normal sex ratio. However, when $D$. affinidisjuncta females are crossed with male $D$. disjuncta there is a significant deviation in the $F_{1}$ sex ratio in favor of females. Among progenies of the cross female $D$. disjuncta $\times$ male $D$. affinidisjuncta is a significant amount of heterogeniety in the sex ratio. If the cross Kipahulu Valley $x$ Hanaula is removed from the data set, the heterogeneity becomes nonsignificant $\left(\chi^{2}=2.212, p=0.7\right)$ and the sex ratio for the remaining progenies is small $\left(\chi^{2}=0.112, p=0.5-0.7\right)$.

Dissections of $F_{1}$ interspecific hybrid males revealed what is the most striking result of these hybridizations (Fig. 6). All male progeny of interspecific crosses were sterile. All $F_{1}$ males from a particular cross were uniform in the sterility they displayed; they were either class I or class II sterile. If the progenies are considered in pairs with reciprocal hybridizations comprising each pair, then $F_{1}$ males of one hybridization are $S l$ and $F_{1}$ males of the reciprocal hybridization are SII. For example, $\mathrm{F}_{1}$ males from the cross female $D$. affinidisjuncta (Kaulalewelewe) $\times$ 

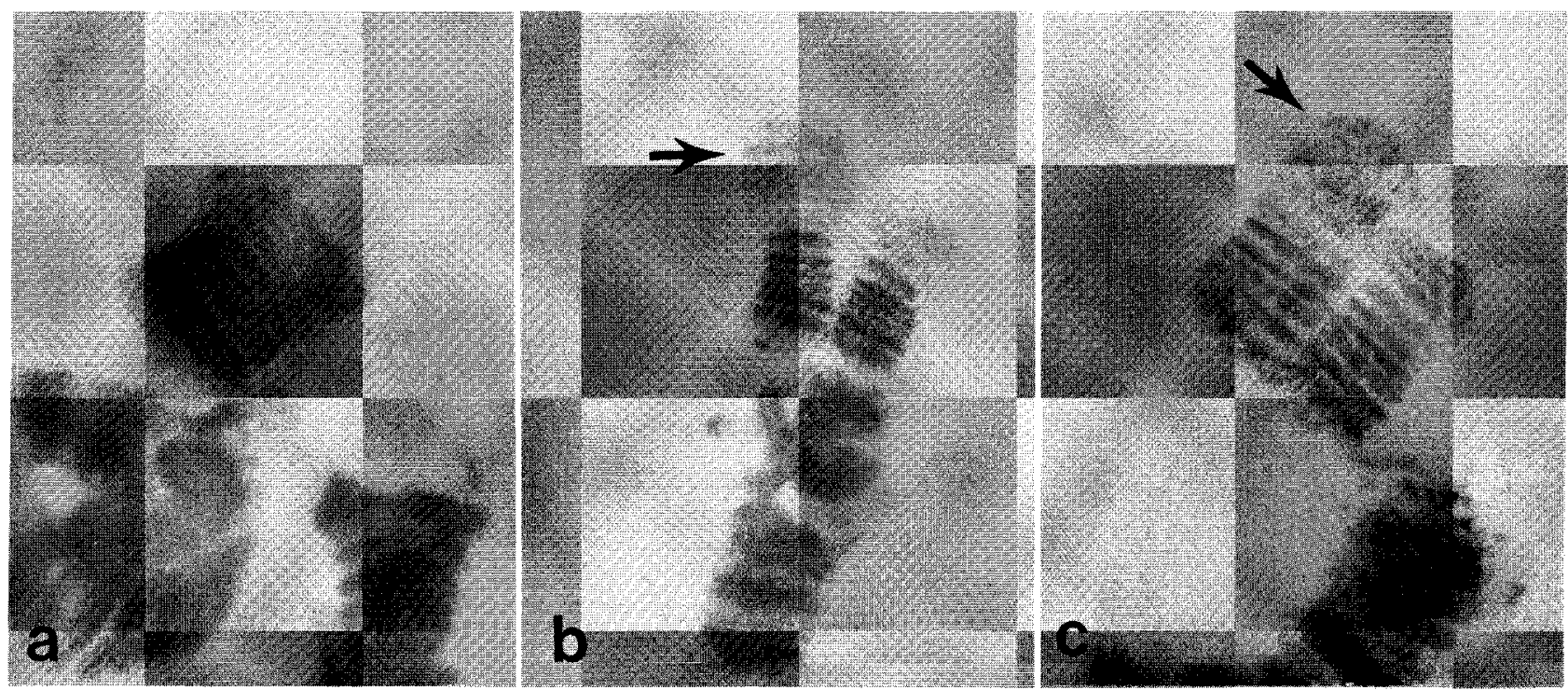

FIG. 4. Salivary gland polytene chromosome 6 of $\mathrm{F}_{1}$ interspecific hybrid larvae. (a) Drosophila affinidisjuncta $+\times$ D. bostrycha, $\delta$. Homologues are well synapsed and cannot be distinguished. (b) Drosophila disjuncta $9 \times D$. bostrycha $\delta$. (c) Drosophila affinidisjuncta $9 \times$ D. disjuncta $\delta$. Chromosome 6 of $D$. disjuncta with characteristic extra band at the distal tip (arrow) is shown on the left in each figure.

TABLE 3. Intraspecific $F_{1}$ hybrid female fertility

\begin{tabular}{|c|c|c|c|c|c|c|}
\hline \multirow[b]{4}{*}{ Population $\mathrm{A} q q \times$ population $\mathrm{B} \delta \delta$} & \multicolumn{6}{|c|}{ Backcrosses } \\
\hline & \multicolumn{3}{|c|}{$F_{1} q 9 \times A \delta 0$} & \multicolumn{3}{|c|}{$\mathrm{F}_{1} q q \times \mathrm{B} \delta 0$} \\
\hline & \multirow{2}{*}{$\begin{array}{c}\text { Success } \\
\text { ratio* }\end{array}$} & \multicolumn{2}{|r|}{ Dissections } & \multirow{2}{*}{$\begin{array}{l}\text { Success } \\
\text { ratio }\end{array}$} & \multicolumn{2}{|r|}{ Dissections } \\
\hline & & Total & No. inseminated & & Total & No. inseminated \\
\hline \multicolumn{7}{|l|}{ D. bostrycha } \\
\hline Apee $\times$ South Hanalilolilo & $\mathrm{F}$ & & $\mathrm{F}$ & & & \\
\hline South Hanalilolilo $\times$ Apee & F & & & F & & \\
\hline \multicolumn{7}{|l|}{ D. affinidisjuncta } \\
\hline Kaulalewelewe $\times$ Hanaula & $7 / 7$ & 21 & 21 & $7 / 7$ & 20 & 20 \\
\hline Hanaula $\times$ Kaulalewelewe & $7 / 7$ & 20 & 20 & $7 / 7$ & 21 & 18 \\
\hline \multicolumn{7}{|l|}{ D. disjuncta } \\
\hline Waikamoi $\times$ Uluini Stream & $7 / 8$ & 25 & 17 & $7 / 7$ & 21 & 21 \\
\hline Uluini Stream $\times$ Waikamoi & $1 / 3$ & 6 & 4 & $0 / 3$ & 4 & 3 \\
\hline \multicolumn{7}{|l|}{ D.disjuncta } \\
\hline Uluini Stream $\times$ Kipahulu Valley & $6 / 7$ & 17 & 11 & $7 / 7$ & 18 & 15 \\
\hline Kipahulu Valley $\times$ Uluini Stream & $7 / 7$ & 18 & 16 & $7 / 7$ & I4 & 10 \\
\hline Kiapahulu Valley $\times$ Waikamoi & $7 / 7$ & 20 & 14 & $7 / 7$ & 20 & 15 \\
\hline Waikamoi $\times$ Kipahulu Valley & $5 / 7$ & 21 & 11 & $5 / 7$ & 16 & 12 \\
\hline
\end{tabular}

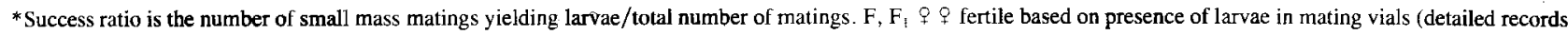
not kept).

male $D$. disjuncta (Kipahulu Valley) are class I sterile while $F_{1}$ males from the reciprocal cross female $D$. disjuncta (Kipahulu Valley) $\times$ male $D$. affinidisjuncta (Kaulalewelewe) are class II sterile. Likewise, the cross female $D$. disjuncta (Kipahulu Valley) $\times$ male $D$. bostrycha (Apee) yields $F_{1}$ males with class I sterility while the reciprocal hybridization generates $F 1$ males of class II sterility.

An even more general pattern emerges when the entire matrix of hybridizations is examined. All interspecific crosses using $D$. affinidisjuncta as the female parent produce $F_{1}$ males having class I sterility and all interspecific crosses using $D$. bostrycha as the male parent produce $F_{1}$ males having class I sterility.

\section{Discussion}

The present investigation has led to more questions than answers. D. E. Hardy, world authority on Hawaiian Drosophila systematics, recognized that specimens collected from Molokai and Maui were closely related to $D$. grimshawi. He described two species, one from Molokai and one from Maui, in 1965. He differentiated $D$. bostrycha from $D$. grimshawi by the yellow color of the femur of the male forelegs. Drosophila disjuncta differed from $D$. bostrycha, as Hardy saw it, only in that $D$. bostrycha males have luxurious ciliation of the tibia on the forelegs, which $D$. disjuncta males lack (Hardy 1965).

Some years later, Baimai and Ahearn (1978) discovered that 


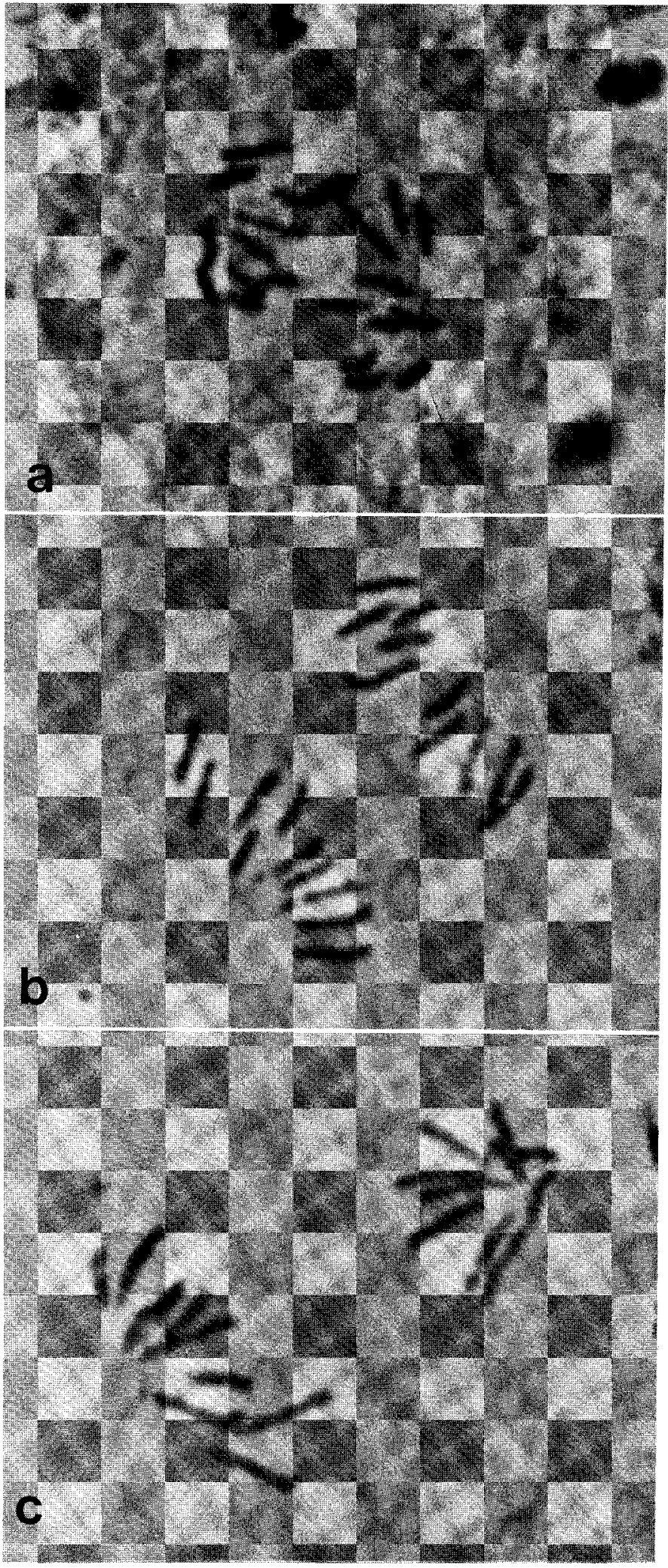

Fig. 5. Chromosomes at mitotic anaphase. (a) Drosophila disjuncta $q,(b) D$. bostrycha $q$, and (c) D. affinidisjuncta $\$$. The dot chromosomes are not always visible. Original magnification $1200 \times$.

the West Maui populations that had previously been lumped under the name $D$. disjuncta, had substantial genetic differences from the populations of East Maui. All five major metaphase chromosomes show heterochromatic blocks, near the centromeres, that are very much longer than those of either $D$.

\begin{tabular}{|c|c|c|c|c|c|c|c|c|}
\hline & \multicolumn{2}{|c|}{$\frac{\text { D. bostrycha }}{\text { Molokai }}$} & \multicolumn{3}{|c|}{$\begin{array}{l}\text { D. disiuncta } \\
\text { East Maui }\end{array}$} & \multicolumn{2}{|c|}{$\begin{array}{l}\text { D. affinidisjuncta } \\
\text { West Maui }\end{array}$} \\
\hline & & $\begin{array}{c}\text { South } \\
\text { Henalitilio }\end{array}$ & spos & waikamoi & Unini Btream & $\begin{array}{l}\text { Kivaturus } \\
\text { valuey }\end{array}$ & Kaulat hemolowe & Hanasule \\
\hline 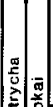 & 訔 & & $\begin{array}{c}\mathbf{F} \\
n=20\end{array}$ & - & - & - & $\begin{array}{c}S \mid \\
n=19\end{array}$ & - \\
\hline$\left|\begin{array}{l}8 \\
0 \\
0\end{array}\right|$ & $\frac{d}{a}$ & $\begin{array}{c}\underset{n=15}{\mathbf{F}} \\
\text {. }\end{array}$ & & $\underset{n=30}{\mathbf{S I}}$ & $\underset{n=20}{S I}$ & $\underset{n=26}{S \mathbf{I}}$ & $\begin{array}{l}\text { SI } \\
n=18\end{array}$ & $\begin{array}{c}\mathbf{S I} \\
\mathbf{n}=26\end{array}$ \\
\hline & 离 & - & $\underset{n=26}{S I I}$ & & $\underset{n=26}{F}$ & $\underset{n=27}{F}$ & $\begin{array}{c}\text { SI } \\
n=27\end{array}$ & $\underset{n=25}{S I}$ \\
\hline 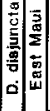 & 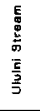 & - & $\begin{array}{l}S I I \\
n=21\end{array}$ & $\underset{\substack{n=69 \\
(17.48}}{\mathbf{F}}$ & & $\underset{\substack{n=40 \\
(12.58}}{\mathbf{F}}$ & $\begin{array}{l}S I \\
n=8\end{array}$ & $\underset{n=26}{S \mid}$ \\
\hline & 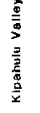 & - & $\begin{array}{c}\text { S I I } \\
n-35\end{array}$ & $\begin{array}{c}F \\
n=26\end{array}$ & $\underset{n=26}{F}$ & & $\begin{array}{c}\mathbf{S I} \\
\mathrm{n}=33\end{array}$ & $\underset{n=26}{S \mid}$ \\
\hline | & 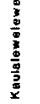 & $\begin{array}{l}\text { SII } \\
\text { n } 16\end{array}$ & $\begin{array}{l}S I I \\
n=26\end{array}$ & $\begin{array}{c}\text { SII } \\
n=31\end{array}$ & $\begin{array}{ll}\text { SII } \\
\pi & 12\end{array}$ & $\begin{array}{c}S I I \\
n=24\end{array}$ & & 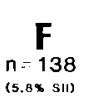 \\
\hline 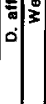 & 蓠 & - & $\begin{array}{l}S 11 \\
n-20\end{array}$ & $\begin{array}{l}S 11 \\
n=27\end{array}$ & $\begin{array}{l}\text { SII } \\
n=27\end{array}$ & $\begin{array}{l}S 11 \\
n 52\end{array}$ & $\begin{array}{c}\mathbf{F} \\
n-34\end{array}$ & \\
\hline
\end{tabular}

Fig. 6. Summary of $F_{1}$ male fertility in intra- and inter-specific hybridizations. F, fertile; SI, class I sterility (block during spermatogenesis); SII, class II sterility (block occurs in spermiogenesis); $n$, number of males dissected.

bostrycha or the East Maui populations of D. disjuncta (see Fig. 1 in Baimai and Ahearn 1978; Fig. 1 in the present paper gives a diagrammatic representation of these karyotypes). Except for the curious fourth chromosome $\left(4 \mathrm{vg}^{2} \mathrm{~h}^{2} \mathrm{i}^{2}\right)$ of Kipahulu valley (Baimai 1975a), these karyotypes are invariable within each species; any single metaphase from any one of the three species is identifiable as belonging to that species without exception. Furthermore, $F_{1}$ males that are hybrids between species were invariably sterile. In view of the preliminary data presenting these facts, Hardy (1978) described the West Maui populations as a third species, affinidisjuncta, stating that it was morphologically indistinguishable from disjuncta. This systematic judgment is amply born out by the new data presented in the present paper.

The divergence of these three species must have occurred comparatively recently. The Maui Island complex, to which they are endemic, has had an unique geological history. East Molokai, in relative terms the oldest at 1.3 to 1.5 million years, is separated from the younger West Maui, aged 1.15 to 1.3 million years, by a shallow channel $(244 \mathrm{~m})$ only $14 \mathrm{~km}$ in width. Haleakala Crater, the volcanic dome of East Maui, is the youngest at 0.4 to 0.8 million years. It is separated from West Maui by a saddle only $38 \mathrm{~m}$ above sea level and $30 \mathrm{~km}$ in width. The entire group of islands (Maui, Molokai, Lanai, and Kahoolawe) has undergone at least two cycles of separation and rejoining because of changes in sea level during the Pleistocene period. Final geographic isolation of Molokai and East and West Maui occurred in the recent geologic past (Macdonald and Abbott 1970).

The standard polytene chromosome band sequence, that of D. grimshawi, is found in all three species. However, the 
TABLE 4. Sex ratios in $F_{1}$ progenies of intraspecific crosses

\begin{tabular}{|c|c|c|c|c|c|}
\hline \multirow[b]{2}{*}{ Population $A \& q \times$ population $B \delta^{\star} \delta$} & \multicolumn{2}{|c|}{ No. of $F_{1}$ adults } & \multirow[b]{2}{*}{$\mathrm{df}$} & \multirow[b]{2}{*}{$x^{2}$} & \multirow[b]{2}{*}{$p$} \\
\hline & $q q$ & 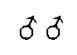 & & & \\
\hline \multicolumn{6}{|l|}{ D. bostrycha } \\
\hline Apee $\times$ South Hanalilolilo & 20 & 24 & & & \\
\hline South Hanalilolilo $\times$ Apee & 19 & 22 & & & \\
\hline \multicolumn{6}{|l|}{$\chi^{2}$ analysis } \\
\hline Total & & & 2 & 0.584 & \\
\hline Heterogeneity & & & 1 & 0.008 & $>0.9$ \\
\hline Pooled & 39 & 46 & 1 & 0.576 & $0.3-0.5$ \\
\hline \multicolumn{6}{|l|}{ D.affinidisjuncta } \\
\hline Kaulalewelewe $\times$ Hanaula & 91 & 78 & & & \\
\hline Hanaula $\times$ Kaulalewelewe & 220 & 179 & & & \\
\hline \multicolumn{6}{|l|}{$\chi^{2}$ analysis } \\
\hline Total & & & 2 & 5.213 & \\
\hline Heterogeneity & & & 1 & 0.075 & $0.7-0.8$ \\
\hline Pooled & 311 & 257 & 1 & 5.138 & $<0.05$ \\
\hline \multicolumn{6}{|l|}{ D. disjuncta } \\
\hline Waikamoi $\times$ Uluini Stream & 304 & 172 & & & \\
\hline Uluini stream $\times$ Waikamoi & 227 & 196 & & & \\
\hline Uluini Stream $\times$ Kipahulu Valley & 247 & 249 & & & \\
\hline Kipahulu Valley $\times$ Uluini Stream & 240 & 199 & & & \\
\hline \multicolumn{6}{|l|}{$x^{2}$ analysis } \\
\hline Total & & & 4 & 42.72 & \\
\hline Heterogeneity & & & 3 & 20.471 & $<0.01$ \\
\hline Pooled & 1018 & 816 & 1 & 22.249 & $<0.01$ \\
\hline
\end{tabular}

frequency of the standard varies considerably between species and even between populations within a species. Curiously, the standard fourth chromosome of $D$. affinidisjuncta is differentiated from the standard in the other species by the presence of two permanent constrictions ( $4 \mathrm{~B}$ and $4 \mathrm{C}$ ) at precise points (Carson 1983, Table 1). It is not known whether these constrictions are associated with nucleolar organizers. This is further evidence of the uniqueness of affinidisjuncta. In $D$. bostrycha at Apee the standard sequence is nearly fixed. The standard arrangement is also nearly fixed in $D$. disjuncta at Uluini Stream and Kipahulu Valley (Table 2). However, in $D$. affinidisjuncta only 15 (Hanaula) to $21.6 \%$ (Kaulalewelewe) of the haploid genomes are standard. Perusal of Table 2 reveals that disjuncta is the most polymorphic of the species with regard to inversions; indeed each of the three populations studied are different from one another, an observation previously suggested by the data of Carson and Sato (1969). Although Carson (1983) states that chromosome 6 , the dot, is invariant for polytene band sequence in the Hawaiian picture wings, $F_{1}$ hybrids involving $D$. disjuncta show that this species has additional terminal bands (Fig. 4).

An early survey of electrophoretic variation in natural populations of the Hawaiian picture wings by Rockwood et al. (1971) included the three species studied here. However, at that time $D$. affinidisjuncta was not recognized as such but was called the West Maui population of $D$. disjuncta. The average heterozygosity, based on only six loci, was 0.067 for $D$. disjuncta (the Kipahulu Valley population) and 0.150 and 0.166 for the Kaulalewelewe and Hanaula populations of $D$. affinidisjuncta, respectively. Their results indicated that phenotypic frequencies for the esterase-B locus were significantly different between $D$. disjuncta and $D$. affinidisjuncta. We briefly surveyed electrophoretic variants of some enzymes and found species differences for malate dehydrogenase (MDH), which is a dimeric protein. Drosophila bostrycha is fixed for a "slow-migrating" electromorph, which it has in common with $D$. grimshawi. Drosophila disjuncta is fixed for a "fast-migrating" electromorph.

Drosophila bostrycha and $D$. disjuncta were included in Ahearn and Kuhn's (1981) histochemical study of aldehyde oxidase distribution patterns in larval tissues and mature imaginal discs. Significant differences in overall activity were seen in the larval hypoderm, salivary glands, and the eyeantennal imaginal disc. With the antennal and leg discs, correlate areas of $\mathrm{AO}$ activity were seen in every species examined. Both bostrycha and disjuncta had activity in the presumptive first antennal segment and the presumptive coxa and, in addition, disjuncta also had activity in the presumptive third antennal segment and the presumptive proximal tibia-femur.

When we discovered the karyotype differences between bostrycha, disjuncta, and affinidisjuncta, we were unable, for lack of technique, to determine whether the heterochromatic additions to each chromosome have been accompanied by a change in the position of the centromere (Baimai and Ahearn 1978). Thus the karyotypes for bostrycha and affinidisjuncta were described in terms of J's and V's and this was reiterated in Table 2 of Carson's 1981 review of homosequential species. However, from our anaphase spreads of each species (Fig. 5), it is clear that the $\mathrm{X}$ and major autosomes are acrocentric.

There are many karyotype alterations owing to heterochromatic changes reported in the Drosophila literature. At least five examples of karyotype differentiation are known between populations within species and these are due to additions of heterochromatin to the dot, the $\mathrm{Y}$, and sometimes the $\mathrm{X}$. Baimai et al. (1983) described six karyotypes for $D$. serido and five 
TABLE 5. Interspecific $F_{1}$ hybrid female fertility

\begin{tabular}{|c|c|c|c|c|c|c|}
\hline \multirow[b]{4}{*}{ Species A $\subsetneq \uparrow \times$ species B $ठ ठ$} & \multicolumn{6}{|c|}{ Backcrosses } \\
\hline & \multicolumn{3}{|c|}{$\mathrm{F}_{1}$ 우 $\times \mathrm{A} \delta \delta$} & \multicolumn{3}{|c|}{$\mathrm{F}_{1}$ q $9 \times \mathrm{B} \delta$ ठ } \\
\hline & \multirow{2}{*}{$\begin{array}{l}\text { Success } \\
\text { ratio* }\end{array}$} & \multicolumn{2}{|r|}{ Dissections } & \multirow{2}{*}{$\begin{array}{l}\text { Success } \\
\text { ratio }\end{array}$} & \multicolumn{2}{|r|}{ Dissections } \\
\hline & & Total & No. inseminated & & Total & No. inseminated \\
\hline \multicolumn{7}{|l|}{$D$. bostrycha $\times D$. affinidisjuncta } \\
\hline South Hanalilolilo $\times$ Kaulalewelewe & $\mathrm{F}$ & & & $\mathrm{F}$ & & \\
\hline Apee $\times$ Kaulalewelewe & $\mathrm{F}$ & & & $\mathrm{F}$ & & \\
\hline Apee $\times$ Hanaula & $7 / 7$ & 20 & 19 & $7 / 7$ & 20 & 20 \\
\hline \multicolumn{7}{|l|}{ D. affinidisjuncta $\times D$. bostrycha } \\
\hline Kaulalewelewe $\times$ South Hanalilolilo & $\mathrm{F}$ & & & $\mathrm{F}$ & & \\
\hline Kaulalewelewe $\times$ Apee & $\mathrm{F}$ & & & $\mathrm{F}$ & & \\
\hline Hanaula $\times$ Apee & $7 / 7$ & 20 & 19 & $7 / 7$ & 20 & 20 \\
\hline \multicolumn{7}{|l|}{ D. affinidisjuncta $\times D$. disjuncta } \\
\hline Kaulalewelewe $\times$ Waikamoi & $6 / 7$ & 18 & 11 & $5 / 7$ & 18 & 14 \\
\hline Kaulalewelewe $\times$ Uluini Stream & $\mathrm{F}$ & & & $\mathrm{F}$ & & \\
\hline Kaulalewelewe $\times$ Kipahulu Valley & $6 / 7$ & 15 & 12 & $6 / 7$ & 21 & 17 \\
\hline Hanaula $\times$ Waikamoi & $7 / 7$ & 21 & 17 & $7 / 7$ & 19 & 19 \\
\hline Hanaula $\times$ Uluini Stream & $7 / 7$ & 21 & 21 & $7 / 7$ & 21 & 20 \\
\hline Hanaula $\times$ Kipahulu Valley & $7 / 7$ & 17 & 17 & $7 / 7$ & 19 & 18 \\
\hline \multicolumn{7}{|l|}{$D$. disjuncta $\times D$. affinidisjuncta } \\
\hline Waikamoi $\times$ Kaulalewelewe & $6 / 6$ & 25 & 23 & $6 / 6$ & 27 & 27 \\
\hline Uluini Stream $\times$ Kaulalewelewe & $\mathrm{F}$ & & & $\mathrm{F}$ & & \\
\hline Kipahulu Valley $\times$ Kaulalewelewe & $3 / 4$ & 6 & 3 & $5 / 5$ & 12 & 9 \\
\hline Waikamoi $\times$ Hanaula & $7 / 7$ & 20 & 18 & $7 / 7$ & 22 & 22 \\
\hline Uluini Stream $\times$ Hanaula & $5 / 5$ & 15 & 15 & $7 / 7$ & 20 & 20 \\
\hline Kipahulu Valley $\times$ Hanaula & $7 / 7$ & 20 & 20 & $7 / 7$ & 20 & 20 \\
\hline \multicolumn{7}{|l|}{$D$. bostyrcha $\times D$. disjuncta } \\
\hline Apee $\times$ Waikamoi & $5 / 7$ & 17 & 14 & $5 / 7$ & 13 & 10 \\
\hline Apee $\times$ Uluini Stream & $\mathbf{F}$ & & & $\mathbf{F}$ & & \\
\hline Apee $\times$ Kipahulu Valley & $6 / 7$ & 20 & 15 & $7 / 7$ & 17 & 17 \\
\hline \multicolumn{7}{|l|}{ D. disjuncta $\times D$. bostrycha } \\
\hline Waikamoi $\times$ Apee & $5 / 5$ & 9 & 8 & $5 / 5$ & 14 & 13 \\
\hline Uluini Stream $\times$ Apee & $\mathrm{F}$ & & & $\mathrm{F}$ & & \\
\hline Kipahulu Valley $\times$ Apee & $6 / 6$ & 15 & 6 & $7 / 7$ & 21 & 21 \\
\hline
\end{tabular}

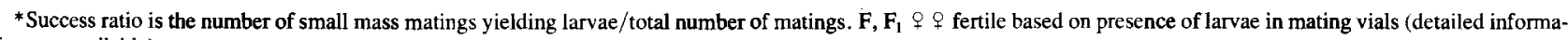
tion not available).
}

karyotypes for $D$. meridionalis both of the repleta group in Brazil. No hybridizations between karyotypic strains were attempted. Drosophila paranaensis, also of the repleta group and endemic to Central and South America, was found to have three karyotypic strains which differ by additions of heterochromatin to the dot (Wasserman and Wilson 1957; reviewed by Wasserman 1982). Thus the dot of strain "a" becomes a small V in strain "b" and a large V in strain "c." Hybridizations within strains yielded fertile $F_{1}$ progeny but between strains " $a$ " and "c" yielded sterile $F_{1}$ males.

In the melanogaster group, D. birchii is endemic to Northern Australia and Papua New Guinea. Baimai (1969) described seven karyotypic strains which differ by additions of heterochromatin to the dot, the $\mathrm{X}$, and the $\mathrm{Y}$ from the basic karyotype of two V's, one J, and one dot. His hybridization studies (Baimai 1970) included only four of the seven strains but revealed that only one of these, collected both in Cairns, Australia, and in Rabaul, Island of New Britain, New Guinea, gave sterile $F_{1}$ males when hybridized with the other three strains. The Rabaul strain also appeared to be differentiated from the others by courtship behaviour. A subcosmopolitan species ranging from the Orient and Australia across the Pacific to South America, D. kikkawai in the melanogaster group has seven karyotypic strains (Baimai and Chumchong 1980). Siblings of $D$. kikkawai, D. leontia, and $D$. bocki, endemic to Thailand and Taiwan, share a karyotype of two V's, one R and one dot. In $D$. kikkawai this karyotype is expanded by heterochromatin additions to the dot and the $Y$; in fact, the dot is never seen. Cursory hybrid studies showed that the strains from Singapore and Brazil yield fertile $F_{1}$ hybrids but that a strain from Sabah, North Borneo, is sexually isolated from the Singapore strain.

None of the previous findings have led to new species designations as our findings did. However, there are two examples of close karyotype relationships being found for species already described on morphological and biogeographical bases. In the immigrans group, $D$. nasuta of the Seychelles has a karyotype of two R's, one V, and one dot. The karyotype of very close relatives, $D$. kepulauana of Borneo and the Philippines and D. albomicans of Thailand and Taiwan, differ by heterochromatin additions to the dot and the Y. In addition, the $\mathrm{X}$ and $\mathrm{Y}$ have fused with one of the rod-shaped autosomes in $D$. albomicans. Only $\mathrm{F}_{2}$ interspecific hybrids involving $D$. albomicans show partial sterility because of 
TABLE 6. Sex ratios in $F_{1}$ progenies of intraspecific hybridizations

\begin{tabular}{|c|c|c|c|c|c|}
\hline \multirow[b]{2}{*}{ Species A $q q \times$ species B $\delta \sigma$} & \multicolumn{2}{|c|}{ No. of $F_{1}$ adults } & \multirow[b]{2}{*}{$\mathrm{df}$} & \multirow[b]{2}{*}{$x^{2}$} & \multirow[b]{2}{*}{$p$} \\
\hline & $q q$ & $\delta \sigma$ & & & \\
\hline \multicolumn{6}{|l|}{$D$. bostrycha $\times D$. affinidisjuncta } \\
\hline South Hanalilolilo $\times$ Kaulalewelewe & 14 & 16 & & & \\
\hline Apee $\times$ Kaulalewelewe & 54 & 66 & & & \\
\hline \multicolumn{6}{|l|}{$\chi^{2}$ analysis } \\
\hline Total & & & 2 & 1.333 & \\
\hline Heterogeneity & & & 1 & 0.026 & $0.8-0.9$ \\
\hline Pooled & 68 & 82 & 1 & 1.307 & $0.2-0.3$ \\
\hline \multicolumn{6}{|l|}{$D$. bostrycha $\times D$. disjuncta } \\
\hline Apee $\times$ Waikamoi & 69 & 72 & & & \\
\hline Apee $\times$ Uluini Stream & 52 & 46 & & & \\
\hline \multicolumn{6}{|l|}{$\chi^{2}$ analysis } \\
\hline Total & & & 2 & 0.431 & \\
\hline Heterogeneity & & & 1 & 0.398 & $0.5-0.7$ \\
\hline Pooled & 121 & 118 & 1 & 0.038 & $0.8-0.9$ \\
\hline \multicolumn{6}{|l|}{$D$. disjuncta $\times D$. bostrycha } \\
\hline Waikamoi $\times$ Apee & 48 & 41 & & & \\
\hline Uluini Stream $\times$ Apee & 101 & 90 & & & \\
\hline Kipahulu Valley $\times$ Apee & 50 & 43 & & & \\
\hline \multicolumn{6}{|l|}{$\chi^{2}$ analysis } \\
\hline Total & & & 3 & 1.712 & \\
\hline Heterogeneity & & & 2 & 0.036 & $>0.9$ \\
\hline Pooled & 199 & 174 & 1 & 1.676 & $0.1-0.2$ \\
\hline \multicolumn{6}{|l|}{$D$. affinidisjuncta $\times D$. bostrycha } \\
\hline Kaulalewelewe $\times$ South Hanalilolilo & 26 & 23 & & & \\
\hline Kaulalewelewe $\times$ Apee & 36 & 32 & & & \\
\hline \multicolumn{6}{|l|}{$\chi^{2}$ analysis } \\
\hline Total & & & 2 & 0.419 & \\
\hline Heterogeneity & & & 1 & 0.00 & $>0.9$ \\
\hline Pooled & 62 & 55 & 1 & 0.419 & $0.5-0.7$ \\
\hline \multicolumn{6}{|l|}{$D$. affinidisjuncta $\times D$. disjuncta } \\
\hline Kaulalewelewe $\times$ Waikamoi & 68 & 56 & & & \\
\hline Kaulalewelewe $\times$ Uluini Stream & 7 & 9 & & & \\
\hline Hanaula $\times$ Waikamoi & 146 & 139 & & & \\
\hline Hanaula $\times$ Uluini Stream & 179 & 140 & & & \\
\hline Hanaula $\times$ Kipahulu Valley & 202 & 137 & & & \\
\hline \multicolumn{6}{|l|}{$\chi^{2}$ analysis } \\
\hline Total & & & 5 & 18.814 & \\
\hline Heterogeneity & & & 4 & 5.295 & $0.2-0.3$ \\
\hline Pooled & 602 & 481 & 1 & 13.519 & $<0.01$ \\
\hline \multicolumn{6}{|l|}{$D$. disjuncta $\times D$. affinidisiuncta } \\
\hline Waikamoi $\times$ Kaulalewelewe & 151 & 134 & & & \\
\hline Uluini Stream $\times$ Kaulalewelewe & 16 & 12 & & & \\
\hline Kipahulu Valley $\times$ Kaulalewelewe & 28 & 30 & & & \\
\hline Waikamoi $\times$ Hanaula & 59 & 53 & & & \\
\hline Uluini Stream $\times$ Hanaula & 271 & 285 & & & \\
\hline Kipahulu Valley $\times$ Hanaula & 269 & 152 & & & \\
\hline \multicolumn{6}{|l|}{$\chi^{2}$ analysis } \\
\hline Total & & & 6 & 34.843 & \\
\hline Heterogeneity & & & 5 & 23.121 & $<0.01$ \\
\hline Pooled & 794 & 666 & 1 & 11.222 & $<0.01$ \\
\hline
\end{tabular}

chromosome imbalance. There was no measureable mating behavior differentiation (Wilson et al. 1969; Kitagawa 1978). Four cactus-breeding species endemic to the Mexican Sonoran desert were initially placed into different subgenera based solely on morphology. However, Ward and Heed (1970) discovered that $D$. pachea, $D$. acanthoptera, $D$. nannoptera, and a species yet to be named shared most of their polytene band sequences and differed karyotypically by additions of heterochromatin to the dot, the $\mathrm{Y}$, and in nannoptera to the rod-shaped autosome creating a V. The nannoptera group was erected to accommodate these four. No hybrids were obtained between any of the species since no matings occurred. 
The basic karyotype for Hawaiian picture-winged Drosophila is five rods and a dot (5R1D). Yoon and Richardson (1978) review six departures from this state owing to additions of heterochromatin to the dot. These are $D$. heedi, $D$. lasiopoda, $D$. limitata, $D$. uniseriata, $D$. psilophallus, and $D$. montgomeryi. Of these only one, $D$. uniseriata of Oahu, has been hybridized to close relatives. Yang and Wheeler (1969) obtained fertile $F_{1}$ females but sterile $F_{1}$ males from both reciprocal crosses to $D$. paucipuncta of Hawaii. They were unable to get matings between uniseriata and $D$. punalua of Oahu. Three additional species show karyotype departures from 5R1D. They are D. prostopalpis with 4R1V1D (Clayton 1971), D. melanocephala with 5R1V (Clayton 1969; Clayton et al. 1972), and D. cyrtoloma with 5 V1J (Clayton 1969). The last case is a striking example in which all major elements are enlarged with heterochromatin but, unlike the subjects of this paper, the heterochromatin creates an extraordinary set of additional chromosomal arms (Clayton 1985). Among these, attempts were made to hybridize melanocephala to a close relative, $D$. hemipeza, but no matings could be obtained (Yang and Wheeler 1969).

Besides bostrycha, disjuncta, and affinidisjuncta, there are seven additional picture wings with heterochromatic variations that do not lead to a departure from the 5R1D karyotype. Drosophila digressa was described by Clayton (1976) as having larger rods and dot than close relatives. Doubling in size of one of the rods occurs in D. orphnopeza and D. gymnobasis (Clayton 1969, 1971). This is also true for the Laupahoehoe population of $D$. setosimentum but this condition is a polymorphism within this species (Clayton et al. 1972). A similar heterochromatin polymorphism has been studied in $D$. silvarentis, which also has enlarged dots (Clayton 1969).

Baimai $(1975 a, 1975 b, 1977)$ carefully investigated similar heterochromatin polymorphisms in $D$. disjuncta, $D$. formella, and $D$. recticilia. He found that in each case the additional heterochromatin lengthening of the rods occurred on a chromosome in which inversions had a breakpoint in the centric heterochromatin. For example, in $D$. disjuncta the $4 \mathrm{vg}^{2} \mathrm{~h}^{2} \mathbf{i}^{2}$ inversions, which we have discussed earlier, are correlated with increased chromosome length. The $\mathrm{h}^{2}$ and $\mathrm{i}^{2}$ right breaks are both in the centric heterochromatin. Baimai hypothesized that centric inversion breakpoints may provide a mechanism for excessive replication of heterochromatin and thereby heterochromatin addition. This, indeed, may be true for some situations. However, such a mechanism cannot explain the origin of the heterochromatin blocks in bostrycha and affinidisjuncta since they are homosequential.

We have made the most exhaustive hybridization studies undertaken for Hawaiian picture wings with the exception of Ohta's (1980) work on strains of D. grimshawi. Yang and Wheeler (1969) had included bostrycha and disjuncta in their experiments. They reported obtaining fertile $F_{1}$ females and sterile $F_{1}$ males but, although the hybrids were dissected, no description of the male sterility was offered.

Results of our intraspecific crosses indicate some genetic differentiation between the populations of affinidisjuncta since the sex ratio is skewed in favor of females (Table 4) and some $F_{1}$ male sterility is seen (Fig. 6). For similar reasons we conclude that the Uluini Stream population of disjuncta is diverging from the others.

The only interspecific hybridization that resulted in an aberrant sex ratio was between affinidisjuncta females and disjuncta males where $F_{1}$ females were in excess (Table 6). All $F_{1}$ hybrid females were fertile (Table 5). All $F_{1}$ hybrid males were sterile (Fig. 6) and, as has been reported in the Results, the block in sperm development occurs at one of two stages depending upon the female and male parents. After trying to model these results it was apparent that they do not correlate with amounts of heterochromatin or with sex chromosome combination or with an interaction of both.

The clear-cut difference in type of male sterility was first encountered by Craddock (1975) in the planitibia subgroup. Her data and unpublished data collected by Kaneshiro and by Ahearn reveal that females of $D$. planitibia crossed to any related species yield $F_{1}$ males with type 1 sterility whereas the reciprocal gives $F_{1}$ males of type II sterility. However, as Chang and Carson (1985) have shown, the only heterochromatic difference is between $D$. hemipeza and the others ( $D$. differens, $D$. planitibia, $D$. silvestris, and $D$. heteroneura). Drosophila hemipeza has less heterochromatin in both the $\mathrm{X}$ and the largest autosome and probably more heterochromatin in the dot chromosome. The only chromosome that was not studied sufficiently to make conclusions was the Y. From genetic analyses of male fertility in $D$. melanogaster we know that seven fertility factors exist on the $\mathrm{Y}$ chromosome. In addition, genetic loci on autosomes and the relationship of centromere and chromosome tips are all critical and necessary to successful sperm development (Williamson 1976; Lindsley and Tokuyasu 1980; Gatti and Pimpinelli 1983). Furthermore, it has been shown that there are genetic elements in the heterochromatin of the $\mathrm{X}$ chromosome and the autosome(s) of $D$. melanogaster that may be associated with fertility factors on the $\mathrm{Y}$ chromosome (see Hilliker et al. 1980 for a review).

Drosophila bostrycha, D. affinidisjuncta, and $D$. disjuncta are outstanding examples of what we have yet to understand about speciation and species divergence. They have undergone karyotypic differentiation through addition and loss of heterochromatin. We know nothing about the mechanism. Carson (1981) states that heterochromatin alterations do not seem to be important in the dynamics of speciation. Certainly such alterations are the single major karyotypic difference between these three but whether this was the initial genetic change we don't know. Yoon and Richardson (1978) are of the opinion that heterochromatic changes lead to phenotypic changes. If there are phenotype differences between disjuncta and affinidisjuncta they certainly have nothing to do with morphology. Interspecific hybrid male sterility is evidence for genetic differentiation but the genetic basis for the sterility is not understood. Polytene band sequences, which reflect gene order arrangements, are shared in common by these three. Only $D$. disjuncta is polymorphic for unique inversions. Such data indicate that the species are related and are diverging but not how. Because they are homosequential with $D$. grimshawi and resemble it morphologically, a $D$. grimshawi like population was most probably the ancestor, but no simple scheme of progressive speciation events correlated with the age of the three volcanoes can be invoked.

There is strong evidence that changes in the genetic basis of courtship behaviour through sexual selection is the primary speciation event for Hawaiian picture wings (Carson 1978). Unfortunately, we have no information on courtship behavior for bostrycha, disjuncta, and affinidisjuncta. Another approach that has been valuable in identifying species relationships is restriction endonuclease cleavage site maps of mitochondrial DNA (Templeton 1983). We suggest such information would be useful in our future work as well. 
support and encouragement throughout the course of this study and for valuable suggestions on the manuscript. Thanks to Drs. H. L. Carson, D. E. Jeffery, K. Y. Kaneshiro, A. T. Ohta, and F. C. Val for assisting with field collections. Laboratory assistance was skillfully provided by Grace N. Nishimura, Linden T. Teramoto, and Glen Y. Shiraki. Dr. T. W. Lyttle graciously allowed us to use his unpublished data. This work was supported by National Science Foundation grants GB27586, GB29288, and BMS 74-22532. In addition, the junior author was aided in part by a grant from the General Research Support funds of the John A. Burns School of Medicine, University of Hawaii.

AHEARN, J. N., and D. T. KUHN. 1981. Aldehyde oxidase distribution in picture-winged Hawaiian Drosophila: evolutionary trends. Evolution (Lawrence, Kans.), 35: 635-646.

AheARN, J. N., and A. R. Templeton. Interspecific hybrids of $D$. heteroneura and $D$. silvestris. I. Courtship success. Evolution (Lawrence, Kans.). In press.

Balmal, V. 1969. Karyotypic variation in Drosophila birchii. Chromosoma, 27: 381-394.

1970. Additional evidence on sexual isolation within Droso. phila birchii. Evolution (Lawrence, Kans.), 29: 149-155.

$1975 a$. Heterochromatin and multiple inversions in a Drosophila chromosome. Can. J. Genet. Cytol. 17: 15-20.

$1975 b$. The relationship between metaphase heterochromatin and polytene inversions in Drosophila. Experientia, 31: 779-780.

1977. Chromosomal polymorphisms of constitutive heterochromatin and inversions in Drosophila. Genetics, 85: 85-93.

BA1Ma1, V., and J. N. AHEARN. 1978. Cytogenetic relationships of Drosophila affinidisjuncta Hardy. Am. Midl. Nat. 99: 352-360.

Baimai, V., and C. Chumchong. 1980. Karyotype variation and geographic distribution of the three sibling species of the Drosophila kikkawai complex. Genetica (The Hague), 54: 113-120.

Baimai, V., F. M. Sene, and M. A. Q. R. Pereira. 1983. Heterochromatin and karyotype differentiation of some neotropical cactus-breeding species of the Drosophila repleta species group. Genetica (The Hague) 60: 81-92.

Carson, H. L. 1969. Parallel polymorphisms in different species of Hawaiian Drosophila. Am. Nat. 102: 323-329.

1978. Speciation and sexual selection in Hawaiian Drosophila. In Ecological genetics: the interface. Edited by P. F. Brussard. Springer-Verlag, New York. pp. 93-107.

1981. Homosequential species of Hawaiian Drosophila. Proceedings of the Seventh International Chromosome Conference. Chromosomes Today, 7: 150-164.

1983. Chromosomal sequences and interisland colonizations in Hawaiian Drosophila. Genetics, 103: 465-482.

Carson, H. L., and K. Y. KANESHIRo. 1976. Drosophila of Hawaii: systematics and ecological genetics. Ann. Rev. Ecol. Syst. 7: 311-345.

CARSON, H. L., and J. E. SATo. 1969. Microevolution within three species of Hawaiian Drosophila. Evolution (Lawrence, Kans.), 23: 493-501.

Carson, H. L., and H. D. Stalker. 1968. Polytene chromosome relationships in Hawaiian species of Drosophila. I. The grimshawi subgroup. Univ. Tex. Publ. 6818: 335-354.

Carson, H. L., and J. S. Yoon. 1982. Genetics and evolution of Hawaiian Drosophila. In The genetics and biology of Drosophila. Vol. 3b. Edited by M. Ashbumer, H. L. Carson, and J. N. Thompson. Academic Press, New York. pp. 297-344.

Chang, L. S., and H. L. CARSON. 1985. Metaphase karyotype identify in four homosequential Drosophila species from Hawaii. Can. J. Genet. Cytol 27: 308-311.

Clayton, F. E. 1969. Variations in metaphase chromosomes of Hawaiian Drosophilidae. Univ. Tex. Publ. 6918: 95-110.

1971. Additional karyotypes of Hawaiian Drosophilidae.

Univ. Tex. Publ. 7103: 171-181.
1976. Metaphase configurations in Drosophila. A comparison of endemic Hawaiian species and non-endemic species. Arkansas Acad. Sci. 30: 32-35.

1985. The meiotic and mitotic chromosomes of picture-winged Hawaiian Drosophila species. I. Drosophila grimshawi and $D$. cyrtoloma. Can. J. Genet. Cytol. 27: 441-449.

Clayton, F. E., H. L. Carson, and J. E. Sato. 1972. Polytene chromosome relationships in Hawaiian species of Drosophila. IV. Supplementary data on metaphases and gene sequences. Univ. Tex. Publ. 7213: 163-177.

CRADDOCK, E. M. 1975. Reproductive relationships between homosequential species of Hawaiian Drosophila. Evolution (Lawrence, Kans.), 28: 593-606.

GatTI, M., and S. PimPiNelli. 1983. Cytological and genetic analysis of the $\mathrm{Y}$ chromosome of Drosophila melanogaster. I. Organization of the fertility factors. Chromosoma, 88: 349-373.

HardY, D. E. 1965. Insects of Hawaii. Vol. 12. Diptera: Cyclorrhapha. II. Series Schizophora, section Acalypterae I. Family Drosophilidae. University of Hawaii Press, Honolulu.

1978. A new synmorphic sibling species of Drosophila from the island of Maui, Hawaii (Diptera). Am. Midl. Nat. 99:350-351.

Hilliker, A. J., R. Appels, and A. Schalet. 1980. The genetic analysis of $D$. melanogaster heterochromatin. Cell, 31: 607-619.

Kitagawa, O. 1978. The genetic basis of reproductive isolation in Drosophila. In The dynamics of speciation in plants and animals. Edited by H. I. Oka and O. Kitagawa. U.S.-Japan Cooperative Science Program Seminar, Oct. 14-18, 1978, Tokyo. pp. 68-741.

LINDSLEY, D. L., and K. T. ToKUYASU. 1980. Spermatogenesis. In The genetics and biology of Drosophila. Vol. 2d. Edited by M. Ashbumer and T. R. F. Wright. Academic Press, New York. pp. 226-294.

Macdonald, G. A., and A. T. ABbott. 1970. Volcanoes in the Sea. University of Hawaii Press, Honolulu.

MONTGOMERY, S. L. 1975. Comparative breeding site ecology and the adaptive radiation of picture-winged Drosophila. Proc. Hawaii Entomol. Soc. 22: 65-102.

OнtA, A. T. 1980. Coadaptive gene complexes in incipient species of Hawaiian Drosophila. Am. Nat. 115: 121-131.

Rockwood, E. S., G. C. Kanapi, M. R. Wheeler, and W. S. STONE. 1971. Allozyme changes during the evolution of Hawaiian Drosophila. Univ. Tex. Publ. 7103: 193-212.

Templeton, A. R. 1983. Phylogenetic inference from restriction endonuclease cleavage site maps with particular references to the evolution of humans and the apes. Evolution (Lawrence, Kans.), 37: 221-244.

WARD, B. L., and W. B. HeEd. 1970. Chromosome phylogeny of Drosophila pachea and related species. J. Hered. 61: 248-258.

WASSERMAN M. 1982. Evolution of the repleta group. In The genetics and biology of Drosophila. Vol. 3b. Edited by M. Ashbumer, H. L. Carson, and J. N. Thompson. Academic Press, New York. pp. 61-139.

Wasserman, M., and F. D. Wilson. 1957. Further studies on the repleta group. Univ. Tx. Publ. 5721: 132-156.

WheEler, M. R., and F. E. Clayton. 1965. A new Drosophila culture technique. Drosophila Inf. Serv. 40: 98.

Williamson, J. H. 1976. The genetics of the Y chromosome. In The genetics and biology of Drosophila. Vol. 1b. Edited by $\mathbf{M}$. Ashbumer and E. Novitski. Academic Press, New York. pp. $667-700$.

Wilson, F. D., M. R. Wheeler, M. HaRget, and Kambysellis. 1969. Cytogenetic relations in the Drosophila nasuta subgroup of the immigrans group of species. Univ. Tex. Publ. 6918: 207-253.

YANG, H., and M. R. WheELER. 1969. Studies on interspecific hybridization within the picture-winged group of endemic Hawaii Drosophila. Univ. Tex. Publ. 6918: 133-170.

Yoon, J. S., and R. H. RICHARDSON. 1978. Evolution in Hawaiian Drosophilidae. III. The microchromosome and heterochromatin of Drosophila. Evolution (Lawrence, Kans.), 32: 475-484. 